\title{
РЕІНЖИНІРИНГ МЕНТАЛІТЕТУ ЛЮДСЬКИХ РЕСУРСІВ - ОБОВ'ЯЗКОВА СКЛАДОВА ПРОЦЕСУ УСПІШНОГО УПРАВЛІННЯ ЗМІНАМИ В СОЦІАЛЬНО-ЕКОНОМІЧНИХ СИСТЕМАХ
}

\author{
${ }^{1}$ Панасюк Р. аспірант, \\ ${ }^{l}$ Петренко В. професор кафедри, доктор екон. наук, \\ ${ }^{I}$ Попова X. аспірант, \\ ${ }^{2} \boldsymbol{Я с і н с ь к а ~ И ̆ . ~ д о к т о р ~ е к о н о м і ч н и х ~ н а у к ~}$ \\ ${ }^{l}$ Украӥна, Івано-Франківський начіональний технічний університет нафти і газу; \\ ${ }^{2}$ Польща, Мазовецька Школа Медична (Варшава), декан відділу медичних наук
}

DOI: https://doi.org/10.31435/rsglobal_ijite/01062018/5662

\section{ARTICLE INFO}

Received 22 April 2018

Accepted 23 May 2018

Published 01 June 2018

\section{KEYWORDS}

enterprise,

personnel,

mentality,

reengineering,

matrix,

ideology,

politics,

economy,

change

\begin{abstract}
The article substantiates the need to improve the known technologies of managing changes in society in general and within its separate socioeconomic subsystems by introducing the technology of reengineering the mentality of human resources as a compulsory component of these processes. The main reason of occurrence of unpreparedness and even resistance to implementation changes of human resources of socio-economic systems in the processes of management of changes, determined by the "path dependency problem" that arise in the processes of transformation of society and its components due to the differentiation of ideological, political and the economic views of the participants, as demonstrated by the example of alternative and dominant-complementary institutional matrices of the western and eastern type. It is demonstrated that for conditions and requirements of the society of a new economy it is more appropriate to interpret the institutional matrix as a result of the union of two dominant-complementary matrices in the form of a rhombus, or diamond, the ideological and economic setups of the sides of which will form such changes in the mentality of human resources of modern socio-economic systems that will not be conflicting, which requires a reengineering of the mentality of human resources, ahead of the development and implementation of key organizational, social, technical and technological changes. The working definition of the concept of "reengineering the mentality" of human resources is proposed and it is established that for its large-scale introduction into the management of changes it is necessary to master the leading personnel of systems by ideological and economic installations of a new diamond-like institutional matrix
\end{abstract}

Вступ. Соціальні, економічні, технологічні і політичні трансформації сучасного світу $є$ наслідком неустанної роботи інтелекту людини і людства, а точніше їх кращих представників агентів змін: вчених, винахідників, інноваторів, раціоналізаторів, інтелектуальних лідерів і т. д. Однак, незаперечним $є$ і той факт, що поряд з існуванням і діяльністю агентів змін обов’язково існують і діють інші учасники процесів змін - т. зв. агенти опору змінам, негативна роль яких щодо результатів i динаміки розвитку суспільства загалом і його окремих складових (державних і міждержавних, галузевих, регіональних і функціональних соціально-економічних систем і їх підсистем) теорією управління змінами оцінюється як критично значуща.

В зв'язку з цим, останнім часом все більше дослідників теоретичних основ, моделей, процесів, інструментів і критеріїв управління змінами звертаються до проблеми місця і ролі людських ресурсів в змінах Гдля прикладу, 1, 2, 3], різноманітним аспектам яких основоположники економічної теорії, методів пояснення принципів і технологій управління економічних та інституційних змін Дуглас Норт (Douglass Cecil North) i Роберт Фогель (Robert William Fogel) на початках їх створення не приділили достатньої уваги в зв'язку із акцентуацією на процесах, причинах і наслідках змін, а не взаємовідносин суб'єктів та об'єктів. 
Однак, виявилось, що причинами невдач і провалів більшості необхідних, добре обгрунтованих і запланованих змін стає поведінка як їх ініціаторів, так і їх противників, які всі разом прийнято називати людськими ресурсами організацій і підприємств. Проте, як це було продемонстровано в [1], керівництво соціально-економічних систем (СЕС) найрізноманітнішого призначення і масштабу традиційно продовжує більше уваги приділяти розробці стратегічних і тактичних планів змін тоді, коли «... для досягнення успіху вони повинні глибоко розуміти людську сторону управління змінами», які реалізується «... лише завдяки колективним діям тисяч, або десятків тисяч працівників, відповідальних за проектування, виконання та життєдіяльність зміненого середовища».

Об'єкт дослідження. Об'єктом дослідження є процеси управління змінами в рамках соціально-економічних систем та причини гальмування чи, навіть, протидії змінам їх людськими ресурсами.

Мета і завдання дослідження. Аналіз глибинних причин протидії людських ресурсів СЕС необхідним і позитивним для цих систем змінам, ідентифікація можливих шляхів мінімізації їх негативного впливу на результати змін, формування рекомендацій щодо удосконалення відомих технологій та інструментів успішного управління змінами.

Дослідження існуючих вирішень проблеми. Серед багатьох причин існування опору будь-яким змінам серед людських ресурсів СЕС, який доводиться долати в процесі впровадження необхідних змін, більшість дослідників називають відсутність у людей інформації про суть змін та їх цілі, страх перед невідомим і невпевненість в майбутньому, можливі фінансові чи соціальні втрати від їх реалізації і т. п.

Однак, на нашу думку, більшість із перерахованих причин є тільки наслідками дії інших чинників, які формують життєві цінності, психологічні установки і ментальність людей та лежать набагато глибше в їх свідомості, законсервовані у вигляді набору ідеологем пануючої в суспільстві ідеології. Недаремно автор праці [4] наголосив, що «Інституціональні матриці формують багатство суспільства і людини завдячуючи економічному розуму і менталітету поколінь», а інший дослідник, аналізуючи причини стагнації трансформаційних процесів в Україні, звернув увагу на домінування в цих процесах правил гри т. зв. інституціональної «Хматриці» [5, с. 31].

Тому, для більш детального дослідження впливу ідеологічних чинників на формування менталітету і ментальності людських ресурсів суспільства і відношення останніх до тих чи інших змін, які відбуваються в суспільстві, та його соціально-економічних підсистемах слід, на нашу думку, звернутись до відомої теорії інституціональних матриць С. Кірдіної [6], яка розвинула іiі на ідеях Карла Поланьї (Karl Polanyi, 1886-1964), Дугласа Норта (Douglass North, 1920-19??), Толкотта Парсонса (Talcott Parsons, 1902-1979) та ін.

В цьому контексті слід вказати на той факт, що тривалий вплив базових ідеологічних, політичних і економічних ідеологем інституціональних матриць західного або східного типу, які в [6, с. 71] інтерпретовані у вигляді теорії інституціональних альтернативних X i Y та домінантно-комплементарних X-y i Y-х матриць, формують у людських ресурсів будь-якої країни i їх організованих спільнот (регіональних i територіальних громад, колективів підприємств, організацій, установ тощо) певний набір переконань і поведінкових стереотипів, який, навіть після революційної або поступової зміни природи цих матриць, протягом певного часу продовжують діяти і тривалий час залишається достатньо впливовими.

Метод дослідження. Для дослідження напрямків поведінкових змін під впливом ідеологічних, політичних і економічних ідеологем звернемось до представлених в [6] графічних інтерпретацій інституціональних матриць (Рис. 1), які, на цілком слушну думку їх автора, формуються базовими ідеологічними установками для матриці X - комунітарною ідеологією, унітарним політичним устроєм i редистрибутивною економікою, а для матриці Y індивідуалістською ідеологією, федеративним політичним устроєм і ринковою економікою. При цьому, однак, звернемо увагу на той факт, що у сучасному світі і у будь-яких його частинах альтернативних X і Y матриць в чистому вигляді уже практично не існує, а чинними $\epsilon$ сучасні моделі соціальної інтеграції у вигляді самих різноманітних варіантів домінантнокомплементарних матриць X-у та Y-х.

Тому виглядає цілком логічним і доцільним виконати аналіз та переглянути умови i результати дії ідеологічних, політичних і економічних установок так званих альтернативних інституціональних матриць у сучасному, радикально зміненому, інтелектуалізованому, демократизованому, лібералізованому і глобалізованому суспільстві та можливих варіантів їх 
видозміни з метою можливої реінтерпретації їх впливу на суспільство і людські ресурси його складових СЕС.

Результати дослідження. Виходячи із вищевказаного, осучаснення інституціональної матриці доцільно, на нашу думку, виконати шляхом іiі інтерпретації у вигляді ромба 3 двох суміщених домінантно-комплементарних матриць X-у та Y-х (Рис. 1), що дозволить отримати і використати інституціональну матрицю нового типу.

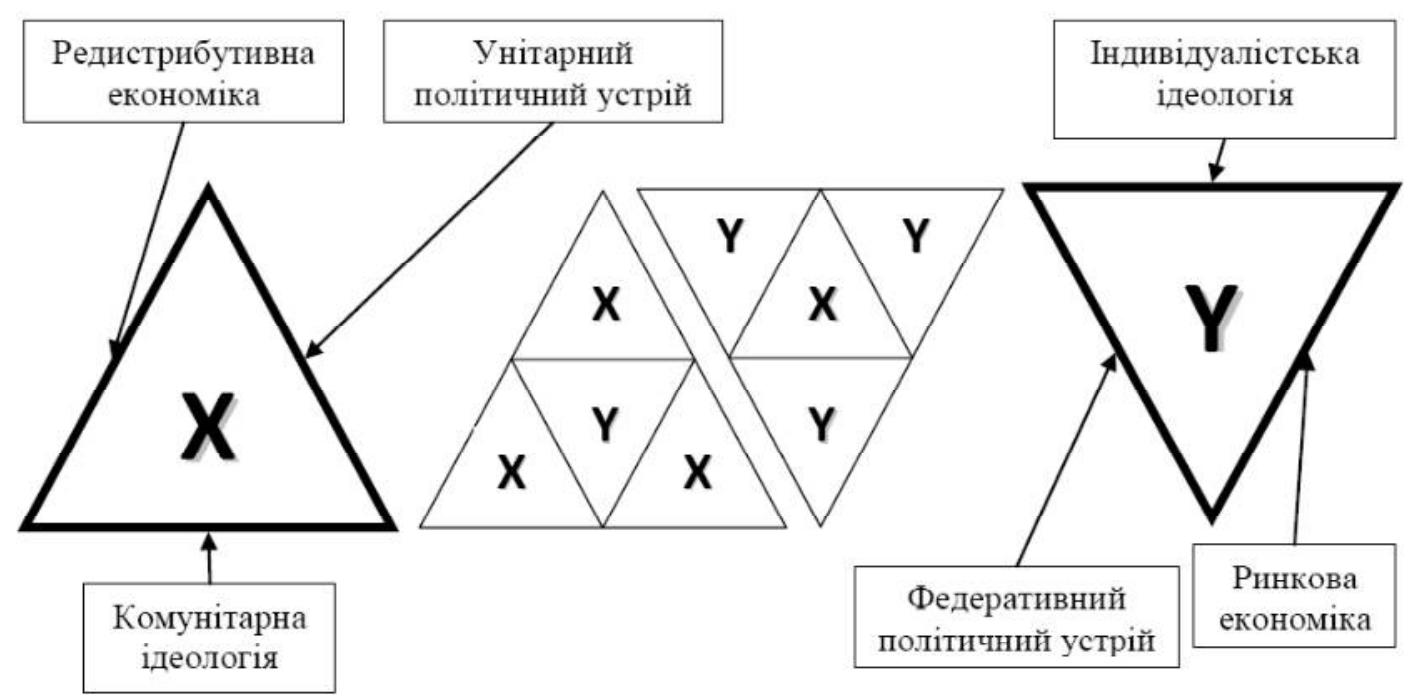

Рис. 1. Альтернативні Х та Y і домінантно-комплементарні X-y і $Y$-х інституціональні матриці (Дж. [4, с. 71])

Об’єднання таких елементів домінантно-комплементарних інституціональних матриць як унітарний i федеративний політичний устрій вважаємо за можливе в зв'язку тим, що 3 позицій теорії управління такі характеристики як структура, прямі і зворотні зв'язки, принципи взаємодії і взаємовідносин між елементарними складовими (підсистемами) генеральної системи несуть функціональне навантаження і не є визначальними в їх альтернативності.

Адже будь-яке сучасне державне утворення незалежно від того, на яких політичних засадах (унітаризму, федералізму чи якихось інших комбінацій) воно відбувається, реалізує щодо своїх людських ресурсів в першу чергу об'єднуючу (а значить комунітарну) функцію. В зв'язку 3 цим більшість сучасних політичних устроїв і поділів суспільства також можна вважати домінантно-комплементарними утвореннями 3 одночасним використанням як унітарних і федеральних, так і комбінованих ознак.

Ліквідувавши ознаку унітарності-федеративності (яка стає внутрішньою структурнофункціональною характеристикою системи), отримаємо можливість об'єднання двох домінантно-комплементарних матриць X-у та Y-х в єдину матрицю-ромб (Рис. 2).

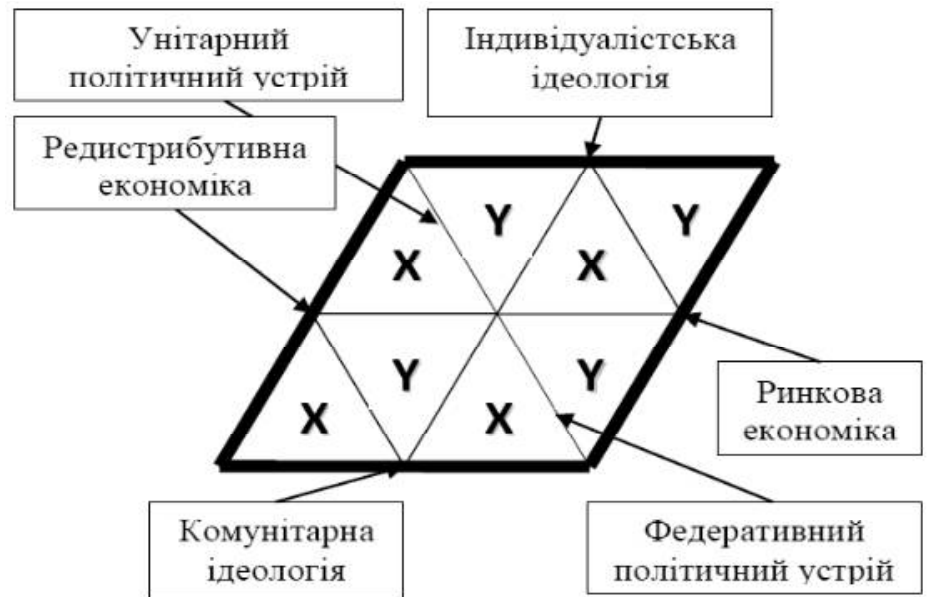

Рис. 2. Нова інституичіональна матриця-ромб сучасного суспільства як сума домінантнокомплементарних $X$-y та $Y$-х інституціональних матрищь (розробка авторів) 
Таким чином, отримана в результаті об’єднання двох трикутних домінантнокомплементарних матриць одна ромбовидна, в якій люди та їх організаційні утворення одночасно перебуватимуть під комбінованими впливами базових варіантів індивідуалістської і комунітарної ідеології та ринкової і редистрибутивної економіки, може стати основою для визначення нових умов впливу на людські ресурси СЕС з метою змін їх менталітету.

Припустивши, що в перехідних суспільствах, які знаходяться в стані трансформаційних реформ, із зміни умов Х-матриці на умови Ү-матриці протягом певного часу відбувається зміна базових ідеологічних установок однієї інституціональної матриці на іншу, прийдемо до висновку, що формування нових цінностей і ментальності людських ресурсів організованих спільнот ідеологічними установками нової ромбовидної (X-y-Y-х) домінантнокомплементарної матриці буде відбуватися за одночасного впливу на їх свідомість і формування цілей та інтересів як ринкової, так i редистрибутивної економік, як індивідуалістської, так і комунітарної ідеологій.

Тобто, життєві цінності, моральність і менталітет людських ресурсів СЕС в процесі змін, які цілком очевидно утворюються і функціонують в площині ромбовидної (X-y-Y-x)матриці, є одночасно як об'єктом традиційних знань, досвіду, звичок і впливів, так і об’єктом нових знань і незвіданого досвіду про зміни, які повинні відбутися.

Саме в цей період проявляється вплив відомого «ефекту колії» - терміну, яким проф. А. Аузан запропонував замінити відоме визначення західних економістів «раth dependence problem» $[7,8]$, коли люди, які тривалий час знаходились під впливами ідеологічних, політичних i економічних установок Х-матриці 3 багатьох причин не хочуть i не можуть ефективно працювати в умовах Ү-матриці (і навпаки), не намагаються пристосуватись до нових умов і навіть чинять активний опір їх впровадженню.

Ліквідація впливу цього ефекту на цілком слушне переконання проф. А. Аузана вимагає змін в як в законах, так і в менталітеті людських ресурсів інституціональної Х-матриці через навчання «вміти впливати на свою владу», «дивитись на 10-15 років вперед», поважати «стандарти, правила і закони» та ін. [9].

Хоча в багатьох аспектах теорія інституціональних матриць [6] 3 певних причин i піддається критичному аналізу [для прикладу, 10, с. 181; 11, 12], ця теорія, тим не менше, демонструє незаперечну присутність «ефекту колії» в усіх транзитних суспільствах, в яких відбуваються кардинальні зміни умов взаємодії таких основних частин суспільства, як влада, бізнес і споживачі. При цьому, наслідки існування і дії «ефекту колії» або «раth dependence problem» дуже негативно впливають на динаміку i результати запланованих соціальних, організаційних, технологічних та ін. трансформацій, що відбувається в зв'язку з гальмуванням процесів формування в соціальному середовищі нових цінностей, цільових установок, нових життєвих практик і моделей поведінки.

Цілком очевидно, що сьогодні інституціональне середовище України і багатьох інших пострадянських країн характеризується «... неоднорідністю інститутів, що перебувають на різних етапах розвитку; асинхронністю їх функціонування, обумовленою циклічністю розвитку інститутів; дискретністю перетворень, зв'язаних зі ступенем підготовленості суб'єктів і агентів до зміни звичних норм і правил〉 [12]. Це пояснюється тим, що людські ресурси будь-якої СЕС, які будучи частками інституціонального простору країни, також є об’єктами впливу альтернативних ідеологем базових інституціональних матриць. За цієї ситуації у частини населення країни (в т. ч. СЕС) виникає певна несумісність звичних, традиційних підходів та сприйняття дійсності 3 вимогами нового інституціонального оточення, що особливо різко проявляється в стосунках між групами людей - прибічниками традицій (яким зручно в існуючій колії традицій і звичок) та провідниками інноваційних змін (які намагаються поміняти колію). В транзитних економіках це приводить не просто до гальмування необхідних суспільству змін в часі, а до падіння виробництва, втрати продуктивності i ефективності, конфліктів, банкрутств і ліквідації підприємств, стагнації підприємництва і т. п., а також втрати віри прогресивно налаштованих членів суспільства в необхідність, доцільність і результативну виправданість змін.

Підтвердженням цього можуть служити і диференційованість результатів опитування Всеукраїнської краудсорсінгової платформи Програми розвитку ООН в Україні у 2012 р., коли на запитання «Що треба змінити, щоб покращити якість життя в Україні?» більшість експертів називали «необхідність змін ставлення, менталітету», а значна більшість пересічних громадяни на перше місце ставили «зміни у сфері державного управління» [13]. Тобто, більшість населення i, очевидно, людських ресурсів СЕС продовжує вважати за необхідне змінювати не 
свої власні погляди, позиції і менталітет, а очікує змін від сторонніх чинників при намаганні зберегти власні інтереси та індивідуальну ментальність.

Слід зауважити, що на вирішення цієї проблеми в багатьох дослідженнях процесів змін в життєустрої людських ресурсів сучасних СЕС були спрямовані зусилля науковців різних країн, якими отримані певні наукові рекомендації і доведена необхідність забезпечення випереджаючих змін у психології, свідомості, ментальності і т. п. носіїв інтелекту - людських ресурсів будь-якої соціально-економічної системи, як умови забезпечення успіху всіх інших необхідних цій системі змін.

Так, незадовго після появи у 1993 році бестселера «Реінжиніринг корпорацій: Маніфест революції в бізнесі» М. Хаммера і Дж. Чампі (Michael Hummer, James Champy) [14], у 1994 році вийшла 3 друку книга Даніеля Араоза (Daniel L. Araoz) і Вільяма C. Сатона (William S. Sutton) «Перепроектуй себе» («Reengineering Yourself»), у вступі до якої авторами було наголошено «... якщо ви не перепроектуєте себе, нічого не зміниться» [15]. Тобто, не змінивши себе не слід очікувати змін у своєму оточенні.

Проте, проголошена авторами дослідження [15] декларація необхідності «перепроектувати себе» була продовжена сформульованими іншими науковцями вимогами «змінити особистісний інтелект» у 2006 р. [16], активізувати талант і здібності людини шляхом «...ментального «реінжинірингу» [...] шляхом особистого розвитку» [17, с. 7], виконати «реінжиніринг процесу мислення» 2017 [18], «реконструювати менталітет» 2017 [19] i, нарешті, «переосмислити управління організаційними змінами» 2018 [20].

Слід вказати, що, починаючи 32000 р., в Україні також з'явились наукові розвідки Мариніч I. В. на тему залежності національної економіки від ментальності нації [21, 22], якою в дослідженні 2012 р. [23] стан українського суспільства було визначено як «віддзеркалення української ментальності». У 2001 р. Семикіна М. В. в роботах [24, 25] наголошувала на необхідності «перебудови ментальності», «трансформації трудового менталітету» і «докорінної зміни спрямованості ментальних установок на суспільному та індивідуальному рівнях». У 2003 р. в монографії [26] Богиня Д. П. довела, що менталітет може бути як активним фактором економічного розвитку, так і суттєвим гальмом на шляху ринкових перетворень, що робить необхідним врахування в процесі розвитку людських ресурсів «особливостей і джерел національного трудового менталітету» [27]. У 2006 р. Лопушинський І. Д. визначив проблему формування національного менталітету основним завдання сучасної української держави [28]. У 2013 році в статті Коваленко Т. В. була доведена необхідність «інтелектуалізації бізнес-процесів» 3 врахуванням «особливостей трудового менталітету працівників» [29], а у 2016 році у вітчизняних електронних ЗМІ з'явилось інтерв’ю П. Шеремета «Україні потрібен соціальний реінжиніринг» [30], в якому він також стверджував, що «... нам потрібна зміна всередині нас самих».

Враховуючи той факт, що «Ментальні трансформації $є$ найбільш складними і завжди потребують переоцінки основних соціальних цінностей та перегляду світоглядних настанов як окремої особистості, так і суспільства в цілому» [31, с. 308], ряд вітчизняних дослідників цілком слушно вважають менталітет людських ресурсів дуже важливою категорією і впливовим чинником інституціональної теорії [для прикладу, 32, 33]. При цьому, не зважаючи на те, що т. зв. «господарський менталітет» вважається економічною категорією [34] i чинником розвитку інституційного середовища [34], дослідження зв'язку між станом менталітету і ментальності людських ресурсів підприємств і організацій та рівнем інтенсивності опору або сприяння змінам останнім часом не виконувались. I це при наявності повного усвідомлення, що «Економічна наука досліджує менталітет на його поведінковому рівні, коли стереотипи й установки суб'єктів, що формуються під впливом ціннісних та ідеологічних орієнтацій, починають виявлятися i впливати на об’єктивний світ» [32, с. 38], а також уже сформульованих рекомендації щодо можливостей «..використати потенціал українського господарського менталітету для реформування інституційного середовища» на мега-, макро-, мезо- і мікроекономічному рівнях національного господарства України [35, с. 78-79].

Проте, більшість вітчизняних експертів, наголошуючи на необхідності «перебудови». «трансформації», «зміни», «переосмислення», «реінжинірингу», «формування» i т. iн. менталітету людських ресурсів СЕС, ніяким чином не пов'язують цей процес з необхідністю попередньої підготовки наступних змін, не вказують на необхідність пріоритетного за часом виконання радикальних змін в менталітеті і ментальності для забезпечення їх успішного ментального «виходу із колії» ще до моменту започаткування процесів обгрунтування, розробки планів і впровадження необхідних підприємствам організаційних, технологічних $і$ т. п. змін. Тому, до останнього часу значна кількість дослідників продовжують стояти на 
традиційних позиціях доцільності простого врахування в процесах управління людськими ресурсами стану їх менталітету та його впливу на результати, а на сьогодні практично відсутні публікації з рекомендаціями щодо необхідності пріоритетного управління змінами менталітету людських ресурсів підприємств до моменту запровадження радикальних змін іншого характеру (організаційних, технічних, технологічних тощо).

Слід зауважити, що серед вітчизняних досліджень шляхів зміни менталітету людських ресурсів можна знайти обгрунтування технології формування професійного менталітету державних службовців [36], визнання і визначення менталітету персоналу підприємств в якості об'єкта менеджменту [37, 38], а також визначення ролі всіх можливих складових (трудового, господарського, економічного, світоглядного, екологічного тощо) менталітету індивідуумів та їх груп в інноваційному розвитку підприємств [39]. Однак, в основі названих досліджень лежить виключно підхід раціонального використання уже існуючого менталітету персоналу підприємств в той час, коли, згідно теорії інституціональних матриць, менталітет і ментальність персоналу підприємств в процесах змін необхідно не проектувати і форматувати, а перепроектовувати $\mathrm{i}$ переформатовувати, не поправляти, пристосовувати і удосконалювати, а радикально змінювати згідно вимог ліберальної але уже глобалізованої та інтелектуалізованої економіки.

В умовах нової економіки це доцільно робити уже не за звичними базовими ідеологічними і економічними установками відомих альтернативних $\mathrm{X}$ аба $\mathrm{Y}$ матриць, i навіть не за критеріями домінантно-комплементарних X-y та Y-х матриць, а за інтерпретацією матриці 3 комбінованим впливом на людські ресурси цих же установок згідно запропонованої нами єдиної ромбовидної X-y-Y-х інституціональної матриці (Рис. 3).

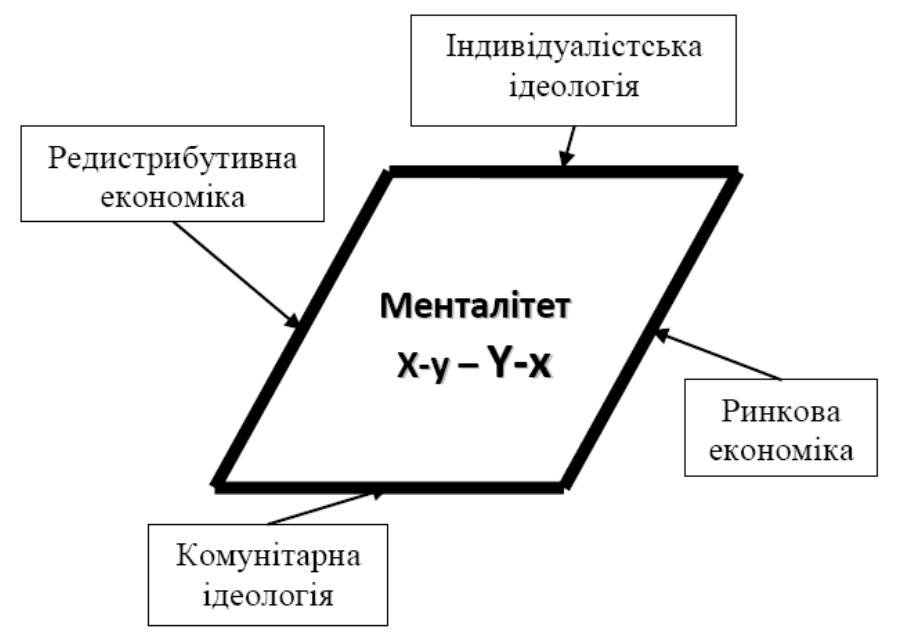

Рис. 3. Зміни менталітету людських ресурсів сучасних підприємств повинні формуватись в рамках ромбовидної інституціональної матриці і під одночасним впливом ї̈ ідеологічних та економічних установок (розробка авторів)

При цьому, менталітет людських ресурсів запропонованої нами інноваційної інституціональної матриці повинен видозмінюватись на засадах знання i використання керівництвом СЕС всіх базових ідеологічних і економічних установок матриці з одночасним налаштуванням на усвідомлене оцінювання, сприйняття i використання всіх позитивних здобутків попередніх інституціональних матриць, заперечення і ліквідації всіх негативних наслідків від їх примусового використання, а також інтеграції людських ресурсів i ïx мотивацією до змін позитивними прикладами уже отриманими і очікуваними наслідками змін.

Отже, певною гарантією реалізації успішних організаційних, технологічних, економічних і соціальних змін в суспільстві і в його СЕС слід вважати випереджаюче виконання необхідних змін в менталітеті їх людських ресурсів i, в першу чергу, управлінських. Ініціатором і мотором необхідних змін повинен виступати управлінський корпус СЕC, а будьяка відома і популярна сьогодні технологія управління змінами повинна в обов'язковому порядку включати етап реінжинірингу менталітету людських ресурсів як соціальнопсихологічну підготовку до поступової і радикальної зміни його життєвих і моральних цінностей, менталітету і ментальності.

Виходячи 3 того, що М. Хаммер і Дж. Чампі (Michael Hummer, James Champy) визначили технологію традиційного реінжинірингу як фундаментальне переосмислення i 
радикальне перепроектування бізнес-процесів для досягнення вагомих покращень у показниках результативності, витрат, якості, рівня обслуговування та оперативності підприємства [40], під процесом реінжинірингу менталітету людських ресурсів СЕС ми пропонуємо розуміти:

прочес сочіально-психологічних змін свідомості і психології людських ресурсів СЕС иляхом зміни життєвих і моральних цінностей, менталітету і ментальності кожної приналежної до СЕС особистості відповідно критеріїв ідеологічних і економічних основ обраної суспільством, керівництвом і колективом СЕС типу інституціональної матриці.

Цілком очевидно, що без використання технології ментального реінжинірингу людських ресурсів СЕС, більшість спроб запровадження інших видів змін в їх основних бізнеспроцесах тільки шляхом нав'язування зверху, диктату керівництва та всупереч діючим переконанням, будь-які заплановані керівництвом радикальні зміни (навіть дуже необхідні) зустрінуть значний опір людей, скоріше всього не відбудуться, а істотне поліпшення результатів функціонування не буде досягнуто.

Однак, не дивлячись на рекомендації багатьох названих вище досліджень, якими доведена необхідність і доцільність розробки та використання різноманітних варіантів технологій реінжинірингу менталітету людських ресурсів підприємств, тільки в [41] було вперше наголошено на тому, що технологія реінжинірингу менталітету людських ресурсів має стати обов'язковою складовою управління процесами змін в соціально-економічних системах.

Висновки. Таким чином, в результаті аналізу впливу на менталітет людських ресурсів підприємств і організацій ідеологічних, політичних і економічних установок інституціональних матриць західного і східного типу, нами встановлено, що:

- головними причинами виникнення опору змінам в суспільстві і його організаційних утвореннях (підприємствах, установах, організаціях територіальних громадах тощо) виступає відомий «ефект колії» або «path dependence problem», який спричинений конфліктом між звичними уявленнями i переконаннями людей із новими вимогами зміненого оточення $\mathrm{i}$ виникає з причин некваліфікованого управління процесами змін;

- гарантією успішної розробки і впровадження організаційних, соціальних, технічних, технологічних і т. д. змін, необхідних для подальшого існування і ефективного функціонування $\mathrm{CEC}$, може і повинно стати використання їх керівним корпусом технології випереджаючого реінжинірингу менталітету людських ресурсів;

- основою технології реінжинірингу менталітету персоналу підприємств повинні стати організація пізнавального розвитку (навчання) людських ресурсів СЕС в комплексі із заходами, спрямованими на соціально-психологічні зміни свідомості і психології людей на основі ідеологічних і економічних установок ромбовидної інституціональної матриці;

- реалізація процесу реінжинірингу менталітету персоналу підприємств згідно рекомендацій ромбовидної інституціональної матриці вимагатиме виконання цілої низки додаткових досліджень, спрямованих на необхідні модифікації в поведінці людських ресурсів СЕС.

\section{ЛІТЕРАТУРА}

1. Kotter John P. HBR's 10 Must Reads on Change Management (including featured article "Leading Change," by John P. Kotter)/ John P. Kotter, W. Chan Kim, Renée A. Mauborgne. - Boston, Massachusetts: Harvard Business Review Press, 2011. - 224 p.

2. Воронков, Д. К. Методологічні засади управління стратегічними змінами в діяльності підприємства : дис... д-ра екон. наук : 08.00.04 / Воронков Денис Костянтинович; Східноукр. нац. ун-т ім. Володимира Даля. - Луганськ, 2011. - 539 с.

3. Jasińska J. Zmiany w organizacjach. Sprawne zarządzanie, sytuacje kryzysowe i warunki osiagania sukcesu / Joanna Jasińska. - Warszawa: Wydawnictwo FREL, 2015. - 546 s.

4. Лавров И. В. Институциональные матрицы формирования богатства: теория и методология / И. В. Лавров // Вестник ОГУ, № 6, 2005, с. 91-96.

5. Jonavicius L. Why Ukraine and Georgia Have Not Used the "Window of Opportunity"? Neo-institutional Analysis Transformational Stagnation in Georgia and Ukraine / Laurynas Jonavicius // UNISCI Discussion Papers. - 2009. - \# 19. - P. 12-37. 
6. Кирдина С. Г. Институциональные матрицы и развитие России: введение в X-Yтеорию / С. Г. Кирдина. - Издание 3-е, переработанное, расширенное и иллюстрированное. СПб. : Нестор-История, 2014. - 468 с.

7. Аузан А. Развитие и «колея» зависимости / А. Аузан // Мировая экономика и международные отношения. - 2017. - Т. 61, №10. - С. 95-105.

8. Аузан А. А. «Колея» российской модернизации // Общественные науки и современность. - 2007. - № 6. - С. 54-60.

9. Экономист Александр Аузан: «Россия превращается в страну менеджеров, охранников, мигрантов и пенсионеров» / [Електронний ресурс]. - Режим доступу : https://www.crimea.kp.ru/daily/25782.5/2766102/

10. Barnett V. Economics in Russia: Studies in Intellectual History / Vincent Barnett, Joachim Zweynert. - Ashgate Publishing Limited Gover Hous, 2008. - 209 p.

11. Руднев А. Особенности социокультурных традиций российского общества / А. Руднев // [Електронний ресурс]. - Режим доступу : http://socupr.blogspot.com/2009/11/blogpost_9106.html

12. Довгань Л. Є. Інституціональне середовище в процесі змін / Л. Є. Довгань, І. П. Малик / [Електронний ресурс]. - Режим доступу : http://www.rusnauka.com/TIP/All/Economica/31.html

13. Чуранова О. Українців спитали, що треба змінити, щоб покращити рівень життя в країні / О. Чуранова // [Електронний ресурс]. - Режим доступу : https://ukrainian.voanews.com/a/uawealth/1569867.html

14. Michael Hammer \& James Champy. Reengineering the Corporation: A Manifesto for Business Revolution. - Harper Business, New York, 1993. - 223 p.

15. Daniel L. Araoz \& William S. Sutton. Reengineering Yourself. Blueprint for Personal Success in the New Corporate Culture. - Wellness Institute, Inc., 2003. - 235 p.

16. Gardner, G. Changing minds: The art and science of changing our own and other people's minds / G. Gardner. - Boston, MA: Harvard Business School Press, 2006. - 272 p.

17. Соммер Д. С. Космическая валюта - наивысшее багатство / Дарио Салас Соммер. М. : Издательство «Кодекс», 2016. - 160 с.

18. Santa Misra. Re-engineering of Thought Process : An exploratory model / Santa Misra // J Psychol Cognition. - 2017. - Volume 2, Issue 1. - P. 75-77.

19. Petrenko V. A psychosemantic approach to reconstruction of political mentality: Research methods and examples / Victor Petrenko, Olga Mitina // Herald of the Russian Academy of Sciences. - 2017. - Volume 87, Issue 1. - pp. 49-62.

20. Tams C. Why We Need To Rethink Organizational Change Management / Carsten Tams // [Електронний ресурс]. - Режим доступу : https:/www.forbes.com/sites/carstentams/2018/01/26/whywe-need-to-rethink-organizational-change-management/2/\#6c86bccb6bb4

21. Мариніч I. В. Моделювання національного менталітету / Мариніч I. В. // Україна: інтелект нації на межі століть / [Ворона В. М., Врублевський В. К., Канигін Ю. М. та ін.] / За ред. В. К. Врублевського. - К.: Інформаційно-видавничий центр «Інтелект», 2000. — С. 280-320.

22. Мариніч I. В. Національна економічна система та ментальність України / В. К. Врублевський, I. В. Мариніч // Україна в XXI столітті: концепції та моделі економічного розвитку / Матеріали доповідей V Міжнародного конгресу українських економістів : В 2-х ч. Редкол.: відп. ред. академік НАН України М. І. Долішній. — Ч. 1. — Львів: Інститут регіональних досліджень НАН України, 2000. - С. 15-20.

23. Мариніч I. Українське суспільство як віддзеркалення української ментальності / I. Мариніч // Українське суспільство 1992-2012. Стан та динаміка змін. Соціологічний моніторинг / За ред. д. е. н. Ворони В. М., д. соц. н. Шульги О. М. - К.: Інститут соціології НАН України, 2012. - С. 335-343.

24. Семикіна, М. В. Трансформація трудового менталітету персоналу у ракурсі економічної інтеграції України до Свропейського Союзу / М. В. Семикіна // Вісник Тернопільської академії народного господарства. - 2001. - Ч. 2. - С. 191-197.

25. Семикіна, М. В. Аспекти перебудови ментальності працівників в системі мотиваційного менеджменту / М. В. Семикіна // Україна: аспекти праці. - 2001. - № 4. - С. 40-46.

26. Богиня Д. П. Ментальний чинник у сфері праці : проблеми теорії та практики : монографія / Д. П. Богиня, М. В. Семикіна ; Ін-т економіки, НАНУ. - К. : Шторм, 2003. - 382 с.

27. Богиня Д. П. Гуманістичні орієнтири управління конкурентоспроможністю людського розвитку / Д.П. Богиня // Регіональні проблеми людського та соціального розвитку: 
тези доп. і повідом. наук.-практ. конф.: В 2 т. - Т. 2 / НАН України, Ін-т економіки пром-сті. Донецьк, 2008. - С. 41-51.

28. Лопушинський I. Формування національного менталітету - нагальне завдання сучасної української держави / I. Лопушинський // Вісник Національної академії держаного управління при Президентові України. — 2006. — № 3. - С. 207-213.

29. Коваленко Т. В. Особливості впровадження сучасних управлінських технологій / T. В. Коваленко // HR-менеджмент: проблеми, стратегії та перспективи: колективна монографія / за заг. ред. І. Б. Швець. - Донецьк: ДВНЗ «ДонНТУ», 2013. - С. 66-74.

30. Хворостина О. Павло Шеремета: «Україні потрібен соціальний реінжиніринг» / О. Хворостина // [Електронний ресурс]. - Режим доступу : http://b.ua/economics/2016/10/03/ 346538_pavlo_sheremeta_ukraini_potriben.html

31. Глушко Т. П. Економічна теорія нації у контексті глобалізаційних процесів (соціальнофілософський аналіз) : дис. на здоб. наук. ступ. д-ра філос. наук за спец. 09.00.03 - соціальна філософія та філософія історії / Т. П. Глушко. - Київ. НПУ ім. М. П. Драгоманова, 2017. - 409 с.

32. Гриценко О. А. Менталітет як категорія інституціональної теорії // Экономическая теория. - 2005. -№1. - С. 35-50.

33. Біленко О.В. Менталітет як інституціональний чинник розвитку людського капіталу / О. В. Біленко // Інституціональний вектор економічного розвитку : зб. наук. праць МІДМУ «КПУ».- 2012.- Вип. 5(2).- С. 26-34.

34. Лусте О. О. Господарський менталітет як економічна категорія / О. О. Лусте // Економічний форум. - 2013. - № 4. - С. 114-120.

35. Осецький В. Господарський менталітет як чинник розвитку інституційного середовища / В. Осецький // Вісник Київського національного університету імені Тараса Шевченка. Економіка. - 2013. - №12(153). - С. 75-79.

36. Філіпова Т.В. Професійний менталітет державних службовців в Україні: технологія формування : дис... канд. наук з держ. упр.: 25.00.03 / Т. В. Філіпова. - Одеський регіональний ін-т держ. управління Національної академії держ. управління при Президентові України. - О., 2006. - 198 с.

37. Дороніна М. С. Трудовий менталітет як предмет менеджменту / М. С. Дороніна, Т. В. Голубєва // Культура народов Причерноморья. - 2009. - № 161. - С. 90-95.

38. Лиманский А. А. Трудовой менталитет как предмет менеджмента / А. А. Лиманский // Бизнесинформ. - 2009. - №3. - C.135-138.

39. Турило А. А. Економічний менталітет і його роль в інноваційному розвитку підприємства / А. А. Турило // Глобальні та національні проблеми економіки. Миколаївський НУ ім. В. О. Сухомлинського. - 2015. - Вип. 7. - С. 508-511.

40. Хаммер М. Реинжиниринг корпорации. Манифест революции в бизнесе / М. Хаммер, Дж. Чампи. - Издательство : «Манн, Иванов и Фербер», 2006. - 287 с.

41. Андибур А. П. Ментальний реінжиніринг як обов'язкова складова процесу управління змінами в соціально-економічних і галузевих системах / А. П. Андибур, М. М. Мельницький, Й. Ясіньска, В. П. Петренко // «Теорія і практика стратегічного управління розвитком галузевих і регіональних суспільних систем». Матеріали VI-ї Міжнародної наук.-практ. конференції (м. ІваноФранківськ, 11-13 жовтня, 2017 року). - Івано-Франківськ:, 2017. - С. 28-30. 